University of Nebraska - Lincoln

DigitalCommons@University of Nebraska - Lincoln

1939

\title{
INCREASE OF SPOROBOLUS CRYPTANDRUS IN PASTURES OF EASTERN NEBRASKA
}

\author{
J. E. Weaver \\ University of Nebraska-Lincoln \\ Walter W. Hansen \\ University of Nebraska-Lincoln
}

Follow this and additional works at: https://digitalcommons.unl.edu/agronweaver

Part of the Terrestrial and Aquatic Ecology Commons

Weaver, J. E. and Hansen, Walter W., "INCREASE OF SPOROBOLUS CRYPTANDRUS IN PASTURES OF EASTERN NEBRASKA" (1939). Papers of John E. Weaver (1884-1956). 9.

https://digitalcommons.unl.edu/agronweaver/9

This Article is brought to you for free and open access by the Agronomy and Horticulture Department at DigitalCommons@University of Nebraska - Lincoln. It has been accepted for inclusion in Papers of John E. Weaver (1884-1956) by an authorized administrator of DigitalCommons@University of Nebraska - Lincoln. 
Reprinted from Ecology, Vol. 20, No. 3, July, 1939 Printed in U. S. A.

INCREASE OF SPOROBOLUS CRYPTANDRUS IN PASTURES OF EASTERN NEBRASKA 


\title{
INCREASE OF SPOROBOLUS CRYPTANDRUS IN PASTURES OF EASTERN NEBRASKA ${ }^{1}$
}

\author{
J. E. Weaver and Walter W. Hansen \\ University of Nebraska, Lincoln
}

The severe drought of 1934 to 1938 has resulted in great losses in the plant populations of native pastures. In Nebraska, little bluestem, Andropogon scoparius, and Kentucky bluegrass, Poa pratensis, have almost disappeared, while big bluestem, Andropogon furcatus, and numerous other important pasture grasses have suffered heavy losses. In addition to shiftings within the plant populations to compensate these losses, such as an enormous increase in side-oats grama, Bouteloua curtipendula, notable and widely spread local extensions have occurred. Over thousands of pastures western wheat grass, Agropyron smithii, has spread widely, and in similar numbers sand dropseed, Sporobolus cryptandrus, has become a dominant or the dominant species in these grazed areas.

Degeneration of prairies under the impact of grazing and subsequent changes in the vegetation under continuous pasturing have been consistently studied over a period of ten years. Examination of extensive field notes taken before the dry period began in 1932 reveals the fact that formerly the sand dropseed occurred only rarely or very sparingly. Following the destructive drought of 1934, it rapidly increased in abundance and in two or three years became one of the most important pasture grasses. Many inquiries have been received from farmers and stockmen regarding this " new pasture grass."

\section{Distribution}

Sporobolus cryptandrus (Torr.) A. Gray is very widely distributed especially in light sandy soils almost throughout the United States. Although abundant westward, it is not common to true prairie (Weaver and Fitzpatrick, '34). Over the broad ecotone where true prairie gradually changes into mixed prairie the best limit of the former is set by the disappearance of Stipa spartea and Sporobolus asper which are replaced in the mixed prairie by Stipa comata and Sporobolus cryptandrus (Weaver and Clements, '38). Sand dropseed is common in all of the western range states, with the exception of California, but is most important in the Great Plains, the Southwest, and in portions of the drainage basins of the Clearwater, Salmon, and Snake Rivers in Idaho and Oregon (Range Plant Handbook, '37).

${ }^{1}$ Contribution No. 115 from the Department of Botany, University of Nebraska.

The publication of extra illustrations accompanying this article is made possible by funds other than those of the Ecological Society of America. 


\section{Character above Ground}

This grass is a tufted perennial of xeric habit. In general the tufts are small but the larger bunches may have a basal diameter of 5 or 6 inches and 30 to 50 leafy stems, which form an open crown (fig. 1). The pithy, solid stems are mostly erect but some usually spread outward at various angles or may even grow parallel to the soil surface. Even vertical stems often spread outward at the base. The leaves are usually 5 to 12 inches long. They are

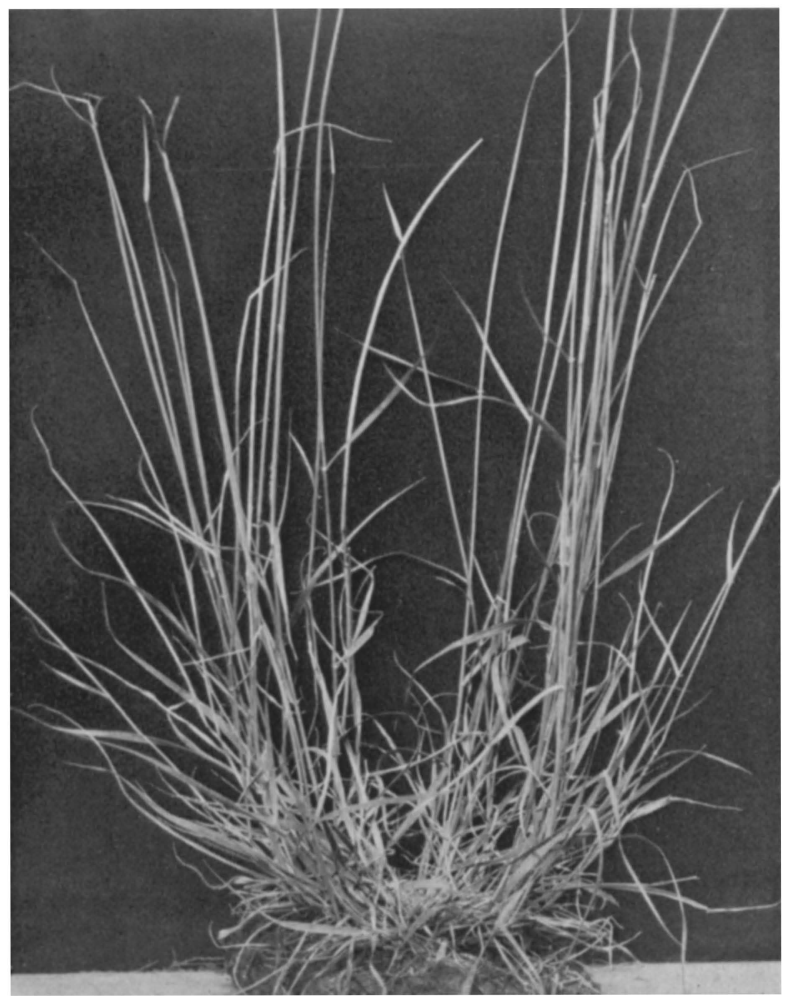

FIG. 1. A fine plant of Sporobolus cryptandrus about 3 feet tall. Note the basal spreading of the stems and the openness of the bunch.

flat, 2 to $5 \mathrm{~mm}$. wide, with conspicuous, long, white tufts of hairs where the blade joins the sheath. Nearly all are confined to the lower half of the mature plant.

Growth in Nebraska is renewed in spring long after that of bluegrass, needle grass, Stipa spartea, June grass, Koeleria cristata, and other species of northern extraction, but earlier than that of the bluestems. By the middle of April the new leaves are an inch or more in length and enough new shoots occur at the bases of the old stems so that stock are tempted to graze the 
bunches. This is discouraged, however, by the dried stem bases of the preceding year which stand stiffly often at an angle of $45^{\circ}$ with the soil (fig. 2).

Growth is fairly rapid and if the plants are ungrazed a height of six or more inches is attained by the middle of June (fig. 3). Production of flower stalks begins about June 15, and during favorable seasons they are borne in great profusion and attain a height of 3 feet. But during dry years they may be reduced to one-third the normal size. The pale or leaden to purplish panicles are partly enclosed in the topmost leaf sheathes. The unenclosed portion spreads somewhat but the panicle is usually narrow. The larger ones are often 15 inches long. Blossoming begins late in June and may continue until October.

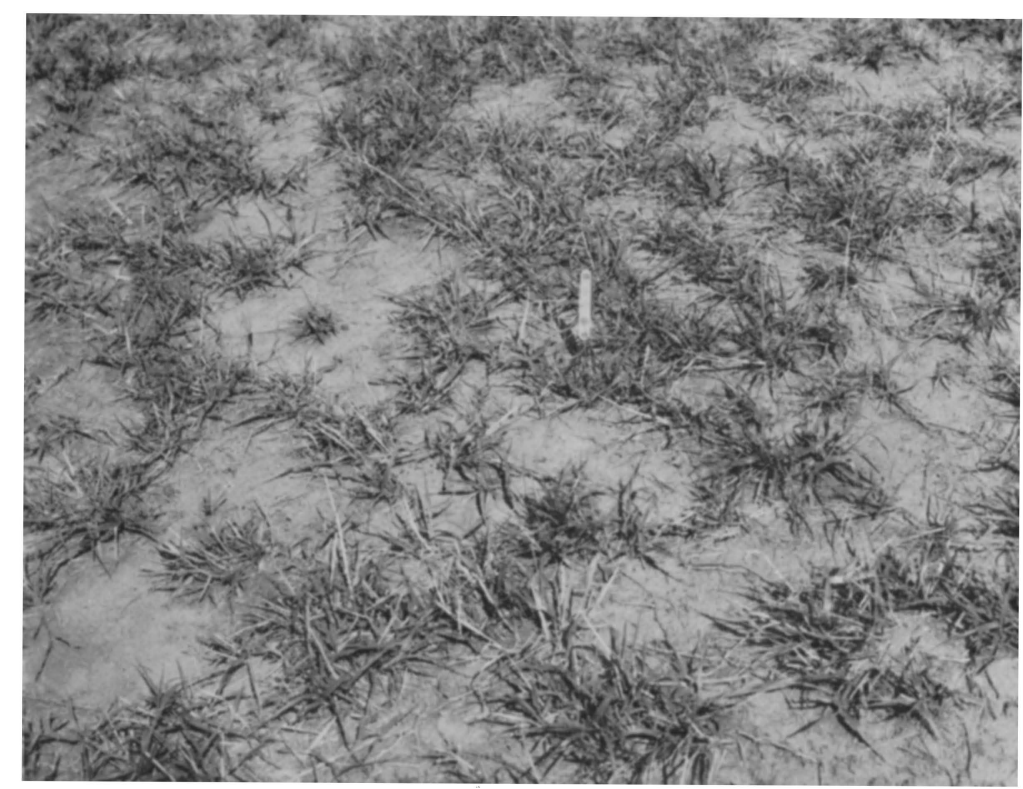

FIG. 2. A thin stand of sand dropseed in a heavily grazed pasture showing the new growth of leaves on April 24, 1938.

The seeds, which mature in late summer or early fall, are produced in enormous numbers. Ten thousand mature seeds have been obtained from a single enclosed panicle. Their total weight was only 0.7 gram. Germination as high as 80 per cent has been obtained but more usually only 25 to 30 per cent. The small seeds gradually fall out of the enclosing leaf sheath and may readily be carried along the ground by high winds to considerable distances. They frequently lie dormant for many years. A germination of 74 per cent after twenty years has been obtained in some experiments where the seeds were buried in pots 3.5 feet below the soil surface (Goss, '24). Seedlings develop rapidly. Tillers appear only a few weeks after germination 
and soon the seedling becomes a small tuft or bunch of leafy stems. Plants with 5 or 6 tillers and 10 to 12 roots were observed the first week in July. Thereafter the growth of ungrazed plants is even more rapid. Several flower stalks are produced and seeds ripen, thus completing the round of life in a single year. When this dropseed is protected or properly grazed it tends to increase in depleted pastures.

When drought comes the leaves roll tightly, the osmotic pressure rising from 10 or 12 to 35 or 40 atmospheres. But soon they unroll and resume photosynthetic activity even after relatively light showers. This is due to the excellent provision for absorption in the surface soil.

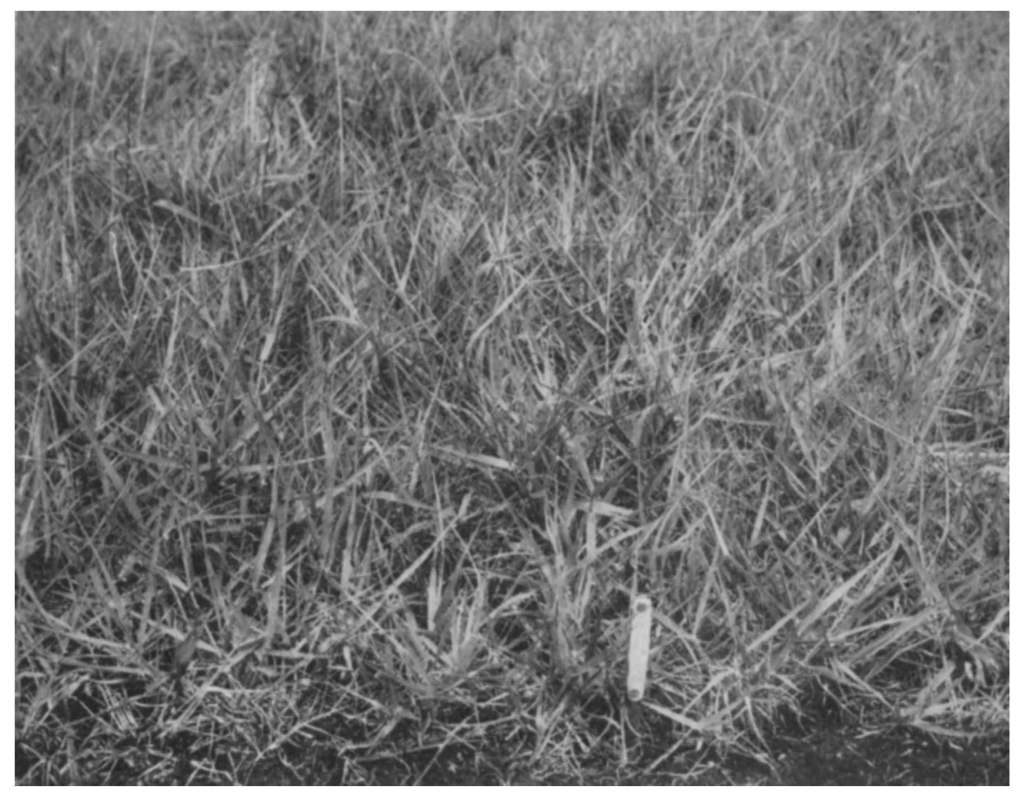

FIG. 3. Detail of Sporobolus cryptandrus in a former bluegrass pasture on June 15, 1938. The plants, which have not yet been grazed, are 6 inches tall.

\section{The Root System}

The mature root system was studied during the dry summer of 1937 and the more favorable one of 1938. In the earlier study the subsoil had been very dry for several years and prevented deeper root penetration. The greatest root depth attained was 22 inches and a maximum lateral spread from the base of the plant was 9 inches. Of the thirteen plants examined, the average number of roots per stem was 4.3. At the second examination soil moisture had penetrated to approximately 4 feet and the longest roots were found growing vigorously to this depth. Even the main roots are only a millimeter or two in diameter and the branches are very fine. As many as 
40 laterals per linear inch are not uncommon. Some of these laterals are several inches in length and densely clothed with fine rootlets of the third and fourth order.

Few roots penetrate directly downward. Nearly all extend outward 4 to 8 inches at various angles to about $45^{\circ}$ with the surface before turning downward. Usually they then pursue a directly downward course. Many extend horizontally throughout their entire length (3-11 in.) in the surface two inches of soil. This portion of the root system is perhaps most freely branched and fine rootlets spread everywhere to within a radius of approximately a foot about the plant. Beneath, the well branched, deeper roots afford an excellent absorbing system. Average number of roots per stem was 3.5, one large plant with 46 stems possessing more than 150 main roots. Thus, the mature root system consists of a vast network of small roots and masses of finely branched rootlets. The soil beneath the plant and several inches on all sides is filled with a dense mat of roots to a depth of about 4 feet. Such an absorbing system is remarkably efficient.

It is believed that with additional depth of moist soil this species would penetrate even deeper under the impact of continued drought. Such has been found to be the case with Stipa spartea where the roots were traced in moist mellow soil to a depth of slightly over 8 feet. This depth, determined in 1938, exceeded any previous depth-record by about 3 feet.

\section{Palatability, Forage Production, and Behavior under Grazing}

Throughout the west, sand dropseed produces a fairly large amount of foliage which is eaten by all classes of livestock. Its palatability, of course, varies greatly, depending upon the climatic conditions under which it grows. Hence the rating is from fair to very good. In eastern Nebraska, both cattle and horses graze it readily, often in preference to western wheat grass. Not only are the leaves eaten but also the stems and flower stalks at all stages of development. The plants are often grazed closely even where forage is abundant. Many stockmen of eastern Nebraska consider it a good forage species.

Total production under constant grazing was determined during 1938. Five clippings were made in the pasture where the growth during the threeweeks interval between clippings was protected by a series of small portable exclosures. The grass in the 30-square-foot area in each pasture exclosure was clipped at the soil surface and from the dry weight produced was subtracted the dry weight of the uneaten remnants of dropseed from adjacent areas of similar size. Thus, the approximate amount eaten by the stock was obtained. Neither lot of clipped areas was used for a second cutting, the exclosures being constantly relocated. The forage removed from the pasture by the cattle was 2.02 tons per acre. 
Owing to the semi-prostrate nature of some leafy stems, grazing does not injure this grass as much as it does many more erect mid grasses (fig. 4). The vigor of this species and its ability to reseed, even under rather heavy stocking, because of prostrate or semi-prostrate flower stalks, adds to its value as a pasture plant. It withstands close grazing far better than Stipa spartea, Sporobolus heterolepis, or even Andropogon scoparius. When protected or properly grazed it tends to increase in depleted pastures. Thus, many of the former bluegrass and little-bluestem pastures of eastern Nebraska are now populated with a good cover of sand dropseed. On the other hand, some

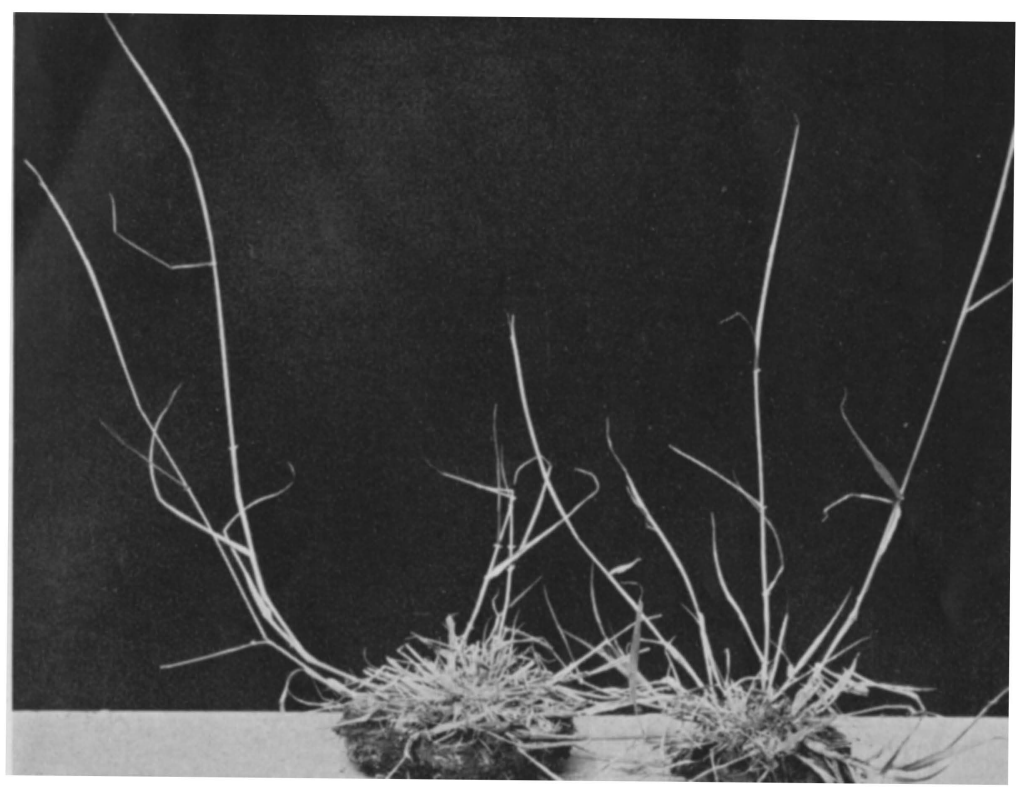

FIG. 4. Well grazed plants of the sand dropseed showing the manner in which prostrate and often more erect flower stalks are left unharmed. These furnish abundant seed for reproduction.

pastures have been so greatly abused during the drought period that the once fine stand of dropseed is now represented only by dead crowns and a few, small, weak survivors of this once abundant grass.

\section{Relation to ERosion}

An important function of range and pasture grasses is that of protecting the soil against wastage by erosion. Studies on the amounts of underground plant materials in various types of pastures as well as their resistance to water erosion under similar conditions of slope, etc., have been made, including some work on sand dropseed (Weaver and Harmon, '35; Kramer and Weaver, '36). The thorough manner in which the roots of this species in a good stand 
occupy the soil is shown in figure 5. Dry weight of this material (about 140 grams per one-half square meter) in the first four inches is 1.5 tons per acre, which is somewhat less than that of little bluestem or bluegrass under predrought conditions. The trampled pasture soil is held almost as firmly, however, and for as long a period of time against water erosion as that occupied by wheat grass or bluegrass.

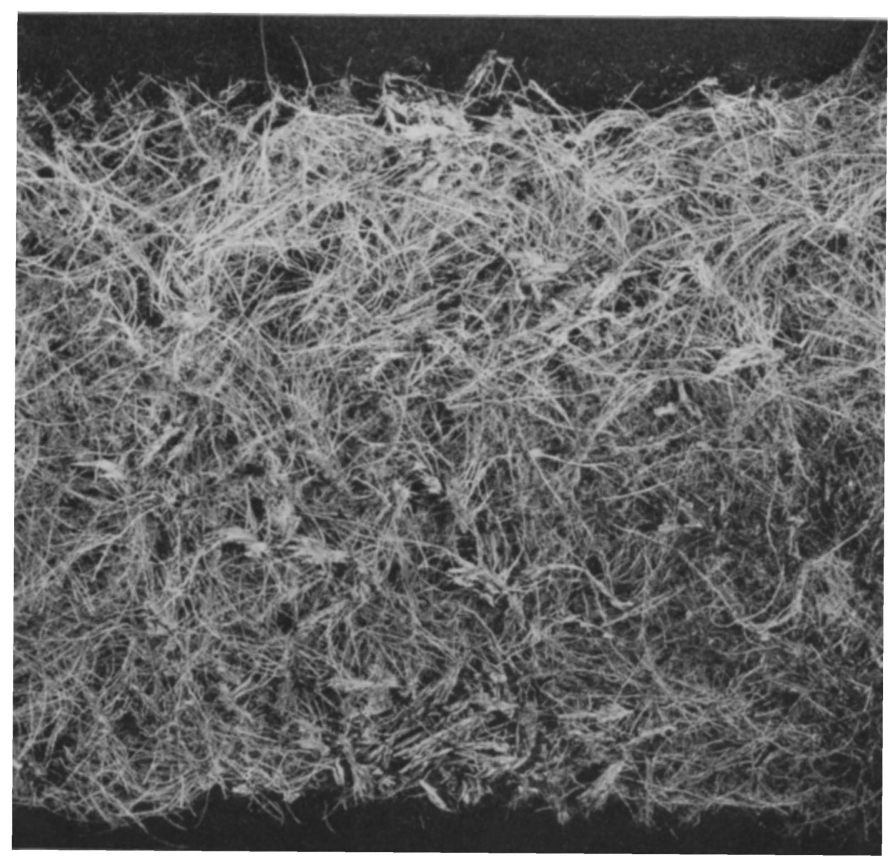

FIG. 5. Roots from a block of sod 4 inches deep and $50 \times 50$ inches in area showing the great underground network of the sand dropseed.

\section{SumMary}

Sand dropseed, Sporobolus cryptandrus, occurred only rarely and sparingly in native pastures of eastern Nebraska before the great drought of 1934. It has since increased so rapidly that it is now one of the most abundant and important pasture grasses. This species, of wide distribution westward, renews growth in early spring, develops rapidly, and is not readily injured by close grazing. It is a prolific seeder and under proper grazing soon reclaims pastures where bluegrass and little bluestem have died. Its resistance to drought is due in part to an excellent root system. In eastern Nebraska, it is of good palatability, produces much forage, and is efficient in protecting the soil against loss by erosion. 


\section{Literature Cited}

Goss, W. L. 1924. The vitality of buried seeds. Jour. Agric. Res. 29: 349-362.

Kramer, J. and J. E. Weaver. 1936. Relative efficiency of roots and tops of plants in protecting the soil from erosion. Conserv. and Survey Div., Univ. Nebr., Bull. 12.

U. S. Forest Service. 1937. Range Plant Handbook. U. S. Dept. Agric.

Weaver, J. E. and F. E. Clements. 1938. Plant Ecology. P. 524. McGraw-Hill Book Company, Inc., New York.

Weaver, J. E. and T. J. Fitzpatrick. 1934. The prairie. Ecol. Monog. 4: 111-295.

Weaver, J. E. and G. W. Harmon. 1935. Quantity of living plant materials in prairie soils in relation to runoff and soil erosion. Conserv. and Survey Div., Univ. Nebr., Bull. 8. 